\title{
日本獣医師 会『会報』
}

\section{論説}

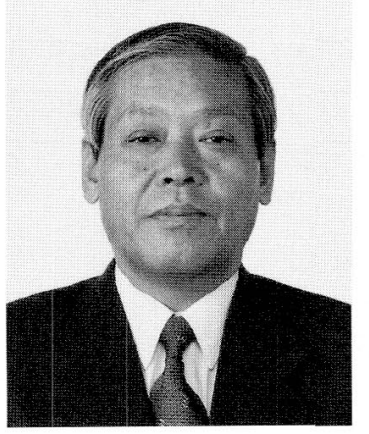

農林水産省の家畜衛生試 験場は，中央省庁等改革の 一環として平成 13 年 4 月 1 日に独立行政法人農業技術 研究機構傘下の動物衛生研 究所として新たな一歩を踏 み出した。家畜衛生試験場 は明治 24 年に農商務省仮 試験場内に設置された 2 研 究室を起源とし，110年に及ぶ長い歴史を持っている. その間, わが国唯一の獣医学国立専門研究機関として, その時々の重要な家畜衛生問題に取組み，わが国の畜産 業の振興に寄与したばかりでなく, 海外技術協力を通じ 発展途上国の開発に貢献するなど，社会の要請に応えて きたと自負している．昨年の口蹄疫発生に対する対応を みるまでもなく，家畜衛生試験場の業績は内外から高く 評価されており，これも多くの関係機関および関係者の ご支援とご協力の賜と深く感謝している.

当研究所は大正 10 年に獣疫調査所として独立，また 昭和 22 年には家畜衛生試験場へ改組と 2 度の大きな変 革に加え，今までに幾多の組織改革を経験した。しか し, 今回の組織改革は独立行政法人化というかつて経験 したことのない質的に異なる組織改革であり，組織体制 ばかりでなく業務運営の方法が従来とまったく異なった 仕組みとなる。むし業務運営の变革を主目的とした改 革といえる。

独立行政法人における業務運営の仕組みは今までと異 なり，国の関与が事前と事後に限られる．主務大臣は3 〜 5 年を見通した業務運営の効率化や国民に対するサー ビスの向上等に関する目標（中期目標：研究機関では 5 年）を示し，法人は中期目標を達成するための計画案 （中期計画）を作成して主務大臣の認可を得る。また， 中期計画とは別に，法人は毎年年度計画を作成し，主務 大臣に届け出る必要がある。法人はこれらの計画に基づ いて業務を実施することになるが，実施にあたって国の 関与はない。しかし，中期計画の終了時には主務官庁に 設置される外部評価委員会による評価があり，中期目標
の達成度など業務実績が厳しく評価される。評価結果は 公開され，評価結果によっては業務内容や運営方針等に ついて改善勧告が出されることになっている。このよう に，法人の業務運営に対する国の関与は事前（中期目標 の提示と中期計画の認可) と事後（評価）に限られ，こ の間の予算の執行や内部組織の設計, 要員の配置など, 業務の実施に必要な事項の多くは法人の自主性と裁量に 委ねられる。また，大学・公立・民間機関等との連携や 共同研究，受託研究の実施や外部資金の導人について も，法人の判断で今まで以上に実施しやすくなる。この ように法人の自主性と独自性が認められたことが法人化 の最大の利点であるが，それだけ責任と透明性，また評 価に耐えうる業務運営と研究成果が求められる. 新研究 所が社会から期待されていることは，動物衛生に関わる 研究ニーズを的確に捉え，それらに着実に応えることで ある，そのためには，研究ニーズを捉えるアンテナを常 日頃から磨くとともに，着実な研究の推進，積極的な研 究成果の公表や広報活動等を通じ，説明責任を果たすこ とが重要と考える。

新研究所の発足に備えるため, 家畜衛生試験場では 2 年前放研究問題の重点化と新研究所の内部組織, 運営 方針等について検討してきた。しかし，いかに準備を進 めたとはいえ, 実際の運営になると思いもかけない問題 が発生することも予想される。そのような場合には，一 つ一つ問題を解決し，よりよい研究所を創るよう努力し なければならない。要は自主性や独立性，柔軟な組織運 営, 広範な連携協力関係, 事務の効率化など, 独立行政 法人の利点をいかに活用して研究所と研究活動を活性化 するかにかかっている，また，常に状況の変化を先取り して，組織体制や柔軟な業務運営のあり方等を検討する 必要がある. そのためには, 全職員の不断の努力と意識改 革, 研究成果に対する厳しい自己評価等が不可欠となる.

動物衛生研究所の目的と責務は, 動物の衛生と疾病問 題の解決を通じて, 家畜生産の損耗防止と安全な畜産物 の生産技術を開発することである。これらに的確に応え るため, 動物衛生研究所は「動物を守る，ヒトを守る」 を理念として, 動物衛生に関わる基礎研究から疾病の診 
断・予防・治療法の開発にいたるまで, 新世紀に相応し い研究を実施しなければならない. 新研究所の発足にあたって, 所員一同心を新たにして
業務遂行に最善を尽くす所存である. 従来の家畜衛生試 験場と同様に諸兄姉の変わらぬご支援とご協力をお願い したい.

\section{会議}

\section{平成 12 年度第 4 回理事会概要}

I . 日 時：平成 13 年 3 月 22 日 (木) $10 ： 00 \sim 12 ： 30$

II . 場 所：ホテルフロラシオン青山 はごろもの間

III. 出席者：

\section{会長：五十嵐幸男}

副 会 長：金川弘司，辻 弘一

専務理事：松山茂

地区理事：森田 彰, 大島寛一，中川秀樹，

手塚泰文，田代昇一，中川平八郎，瀧口次郎， 景浦忠徳

職域理事：竹内 啓, 山元敏進, 清野光一, 藤沢忠世，川西昭喜，山崎省二

監事：鈴木兵一，廣岡小波，原 京平

事 務 局 : 朝日光久事務局長ほか

IV. 議 事:

【報告事項】

1. 業務概況等の件

2. 獣医学教育のあり方に関する懇談会の件

3. 獸医師総合福祉生命共済制度発足の件

4. 監視伝染病等防疫体制支援事業の件

5. 獣医師生涯研修事業の件

6. 学会会則等関係規程の一部を改正した件

7. 平成 14 年度学会年次大会の開催計画の件

8. 動物用医薬品指示書の発行等に関する件

9. 三宅島雄山噴火災害動物救護活動の件

【議決事項】

第 1 号議案 平成 13 年度暫定予算編成の件

第 2 号議案 平成 13 年度一時借入金の最高限度額等 を定める件

第 3 号議案 地区獣医師大会の決議要望事項に関する 件

第 4 号議案 総会及び全国獣医師会会長会議の運営方 法を改める件

第 5 号議案 社団法人仙台市獣医師会の入会の件

第 6 号議案 定款施行細則の一部改正の件

【協議事項】

平成 13 年度事業計画（案）の件

V. 概 要:

【会長挨拶】

冒頭, 五十嵐会長から概要(1)獣医師生涯研修事業につ
いては, 運営委員会においてポイントの申告手続き等に ついて検討が行われていること。(2)監視伝染病等防疫体 制支援事業に係る研修会の開催等については, 地方獣医 師会には多大なるご尽力をいただいたこと. (3)獣医学教 育のあり方に関する懇談会の答申は関係各所へ配布して いくこと. (4)豚コレラの撲滅対策については, 予防接種 中止の後も例外的な予防接種が許可されることとなり， 今後は動物用医薬品指示書 (指示書) により，農家が自 ら予防接種を行うことも想定されることから，今後は指 示書発行のあり方について検討を行う必要があることな どの挨拶があった.

【議長就任・議事録署名人の選任】

続いて, 会長が議長に就任し, 森田, 山元両理事を議

事録署名人に指名して，ただちに議事に入った.

【報告事項】

1. 業務概況等の件

前回理事会（11月21日）以降の業務概況について, 松山専務理事から報告が行われた。

2. 獣医学教育のあり方に関する懇談会の件

獣医学教育のあり方については, 獣医学教育連絡会議 (代表は五十嵐会長) から，昨年 12 月，広く一般の学識 経験者によって構成される獣医学教育のあり方に関する 懇談会に対し，国民的見地から国公私立大学における獣 医学教育の充実と国立大学獣医学部の適正な規模および 配置に関して諮問したが，このたび教育組織（講座数， 教員数）の充実，国立大学の 10 獣医学科を $3 \sim 4$ の獣医 学部に再編整備の必要性等を内容とする答申が提出され た旨が金川副会長から報告された。

3. 獣医師総合福祉生命共済制度発足の件

本共済制度は，当初，発足の条件が加入者 5 千人であ ったが，金融庁の許可を得て，4月 1 日から発足できた こと,さらに制度存続のために更なる加入推進を依頼し たいことが松山専務理事から説明された。

4. 監視伝染病等防疫体制支援事業等の件

本事業は，農水省の指導の下に日本中央競馬会の助成 金を財源とする(財)全国競馬・畜産振興会の 3 年間の助成 事業として，家畜伝染病予防法一部改正に基づく診療獣 医師による初動防疫体制確立のために実施するもので， 本年度は家畜疾病総合情報システム監視伝染病（牛編） の獣医師向けCD-ROM および畜産農家向けINT（ホー ムページ）の作製と，これを用いた研修会の開催，保健 衛生指導マニュアル研修会の開催，さらに疫学に関する 獣医師へのアンケート調査等を実施した。 